Article

\title{
Promoting Adaptive Reuse in Ontario: A Planning Policy Tool for Making the Best of Manufacturing Decline
}

\author{
Marcello Vecchio * and Godwin Arku \\ Department of Geography, Western University, London, N6A 5C2, Canada; E-Mails: mvecchi@uwo.ca (M.V.), \\ garku@uwo.ca (G.A.) \\ * Corresponding author
}

Submitted: 25 April 2020 | Accepted: 21 July 2020 | Published: 29 September 2020

\begin{abstract}
The exodus of manufacturing jobs from industrialized cities has increasingly altered the way municipalities plan and cope with buildings and areas that once served as industrial and economic centres. Now these often derelict and costly structures sit as an eyesore in many communities which experience symptoms of post-industrialism. The practice of adaptive reuse is a unique concept of city building, where demolition and traditional brownfield redevelopment have been common practice. Though an already established method, adaptive reuse is becoming increasingly popular due to a greater intensity to protect heritage, reuse materials and structures, and offer unique architectural spaces, there has been a demand to reuse former industrial buildings for other uses such as commercial and recreational spaces. To achieve this, there must be sufficient policy in place to incentivize and mitigate the increase cost and risk which are usually associated with this type of development. This article will focus specifically on Ontario, Canada, and the current Official Plans of all 51 of the province's cities, and how they are addressing adaptive reuse in former industrial areas and unique ways in which they address this problem. A content analysis of the documents showed that there is a wide difference in reuse contextualization and suggested policy directives. However, Cities in Ontario have proposed that affordable housing, intensification, revitalization in the urban core, and creating spaces for creative and vibrant industries can be addressed by the promotion of reuse in the community. For those with strong industrial history, the applicability of reuse allows for communities to preserve their industrial heritage, while at the same time shift uses to the new economy.
\end{abstract}

\section{Keywords}

Canada; cities; economic development policy; industrial decline; land use planning; Ontario

\section{Issue}

This article is part of the issue "Planning for Local Economic Development: Research into Policymaking and Practice" edited by Godwin Arku (University of Western Ontario, Canada) and Evan Cleave (University of Toronto Mississauga, Canada).

(C) 2020 by the authors; licensee Cogitatio (Lisbon, Portugal). This article is licensed under a Creative Commons Attribution 4.0 International License (CC BY).

\section{Introduction}

What are cities doing with their former industrial lands? This article explores how cities in the Province of Ontario, Canada are approaching this question through a comprehensive analysis of Official Plans. While situated in an urban planning context, this issue is also very much one of local economic development practice as it considers how official planning is used to respond to economic change, as well as a tool to stabilize, redefine, and grow local economies. Additionally, these planning efforts are embedded within the transformation of traditional economies, which relied heavily on manufacturing and resource extraction, to new-economies that rely on knowledge and service-based industries (Bunting \& Filion, 2006; Hobor, 2013; Sands, 2010). These servicebased industries require human capital-and as a result, cities are now in need of housing (both quality and quantity) to help attract and retain workers.

Over the last two decades, in particular, cities in Ontario have experienced the pervasive trends of deindustrialization and economic restructuring similarly seen 
in other industrialized societies. Historically, manufacturing formed the backbone of Ontario's economy, as industrialization was part of government economic policy for well over a century. The province's aggressive industrial policy has been helped by its proximity to the United States which facilitated trade, and the availability of capital, manpower, and resources-all of which gave the province and its cities the necessary ingredients to build their economies around manufacturing and related activities. Since the early 2000s, however, hundreds of industrial plants across Ontario have shut their doors, no longer able to keep afloat in an increasingly globalized and post-industrial economy (Bourne, Britton, \& Leslie, 2011; Bradford, 2010).

This transition has had an impact on the urban landscape of cities, due to where industrial sites were located. Traditionally, industry focused on minimizing the transportation costs of materials and the finished product to large urban markets, as well as the access to an ample low wage workforce (Blair \& Premus, 1987). Thus, manufacturing and industrial firms were typically located in cities to make use of these locational proximity advantages, including access to rail lines (Ward, 1998). Surrounding the industrial plants were often lowdensity residential and commercial uses to serve the large working-class populations.

Due to the historic location of industrial complexes, many of the current abandoned industrial buildings are situated in prime areas in the city, often close to the downtown core and major transportation nodes. In most cities, the buildings are often below the standards of other areas in the city and therefore have been relatively untouched by the real estate market. As a result, the spaces once occupied by factories have not been replaced and these areas now sit unused, slowly deteriorating as a stain on the urban landscape (Collaton \& Bartsch, 1996). Indeed, the development trends from the last several decades have increased the chance of urban industrial buildings in downtown areas to become vacant and derelict (Wilson, 2010). Many cities have been inundated with a large supply of expensive, use-specific, and sometimes hazardous properties.

Beyond the aesthetics, the lack of redevelopment also means that cities are not maximizing tax revenue, nor are they addressing issues of urban sprawl. Eidelman (2010) argues that it is underutilized lands within the core, which have the opportunity to increase the marketability of these areas and prevent the often easily profitable, sprawl-like development. The impact of this is two-fold. First, in Ontario and other advanced economic regions, cities are increasingly responsible for providing services to residents (rather than upper levels of government), so a lack of economic activity in these areas means that less capital is available for reinvestment. Similarly, there has been concurrent movement within city planning to increase population density within urban cores. In part, the push for intensification is a reaction against the prevailing sprawling patterns of urban devel- opment. The policy foundation for this in Ontario is situated in the Places to Grow Act of 2005 (Government of Ontario, 2005). This act was paramount in addressing the growing concerns of urban sprawl within the populated Greater Golden Horseshoe (a relatively small geographic area of Ontario which accounts for $24.5 \%$ of Canada's entire population). The province has made it clear that through practices such as intensification, brownfield redevelopment, and core revitalization, cities can address the challenges faced in urban areas today. As a result of this and other guiding provincial policies, there is a need for cities to find adaptive reuses for these underutilized buildings which are often found in the core and most economically deprived areas of the city. Thus, concepts of infilling and brownfield development have become synonymous with contemporary planning and private sector activity in the last decade (de Sousa, 2017). However, in a climate characterized by financial stress, there is a lack of direct financial assistance to remediate the risks which come with brownfield and industrial reuse projects (Hayek, Arku, \& Gilliland, 2010), rather the Province prefers a less intrusive voluntary cleanup approach that has created a reactive response by cities and developers (de Sousa, 2017).

Despite this increase in identifying the benefits of building reuse, there is a missing link when considering how Ontario municipalities are guiding their policy collectively and what themes of industrial building reuse are dominant. It is well understood that current industrial and economic practices in a specific location are pathdependent on the history of economic composition and decisions made by stakeholders (Martin \& Sunley, 2006). Thus, a city's stock of underutilized industrial buildings is indicative of the unique historic timeline of that locale.

In light of this context, where cities need to consider what to do with these areas, this article asks: How are cities contextualizing and responding to local economic development change-specifically related to industrial and manufacturing decline-within their official plans? To evaluate this question, there are three major areas that this article will focus on: (1) catalogue economic development contextualization within Official Plans, including identifying specific strategies; (2) identify emerging themes related to adaptive reuse within the policy; and ( 3 ) investigate whether the local economy (through its industrial base) impacts what policies appear in these plans.

This investigation provides insight into how cities choose to create policy for reuse based on their own unique localized factors and creative incentive platforms. Understanding the policies and themes within the document can provide a useful tool for comparing how market stakeholders are reacting to this policy and create potential for future studies into the stakeholder-policymaker interaction. This comes from the well-discussed relationship between land-use policy and actual development practices (Leffers, 2018). 


\subsection{Local Institutional Context for Planning in Ontario}

All levels of government regulate land use in Canada, each with their own distinct jurisdiction and legislative powers. In Ontario, the province enacts planning policy framework through legislative tools including the Planning Act (1990; Government of Ontario, 1990a), Ontario Heritage Act (1990; Government of Ontario, 1990b) and the Provincial Policy Statement (2005 and 2014; Ministry of Municipal Affairs and Housing, 2005, 2014) which are meant to guide municipalities in their localized land use planning. Despite the broad provincial legislation, local governments have traditionally been the greatest actors of land-use control, which has occasionally been critiqued as an inhibitor to more collective regional planning (Eidelman, 2010). The policy vehicle for local planning is the Official Plan, a binding piece of legislation that describes how land, infrastructure, and planning objectives should be utilized within the municipality (Ministry of Municipal Affairs and Housing, 2010). These documents are an imperative piece of policy when dictating the process and trajectory of land and building use, within their jurisdictional area.

In Ontario cities, this presents itself as Official Plans; a provincially mandated policy document that each municipality must pass through their governing body and must be regularly revised and updated (Government of Ontario, 1990). The Planning Act requires municipalities to update their plans ten years after a municipality prepares a new comprehensive Official Plan or every five years after an update is done through an amendment to the plan. There were cities who had plans dating back to the 1980s (e.g., Brantford) and several in the 1990s. Though this itself, is no indication of whether cities are accounting for economic decline, it does bring up questions of how plans whose main structures predate NAFTA (which was replaced in 2019 by USMCA) adequately account for modern economic trends in their planning policy. These policy documents are typically written inhouse by municipal planners, but at times they are contracted out to private consultants.

From this central document, development of urban space (i.e., vacant industrial building reuse) is controlled through secondary plans, Zoning By-Laws, and Community Improvement Plans. Furthermore, direct measures are also available, including financial incentives such as waiving development charges, breaks on property taxes, and providing height and density bonuses used by municipalities to become a partner in the process (Hayek, Novak, Arku, \& Gilliland, 2010; Shipley, Utz, \& Parsons, 2006). These direct measures are done on a case-by-case basis, so interpreting the success of their applications has to be on an individual development project level.

\section{Methods}

As noted, this article seeks to understand how cities in Ontario are contextualizing and responding to local eco- nomic development change within their Official Plans and to determine if local economic realities influence policy. To achieve this, a comprehensive content analysis was performed on the Official Plans for the 51 cities in the province. In Ontario, cities are municipalities that have populations over 10,000 and have applied and received official designation based on the parameters set out in the Municipal Act (2001; Government of Ontario, 2001). Data was collected before Richmond Hill officially became Ontario's 52nd city. There are several reasons why these documents are key sources of analysis. First, all cities in Ontario have an Official Plan as they are mandated by the province who holds strong institutional control over cities. Second, all Official Plans are publicly available on city websites. Third, the plans contain information about how the built environment within the jurisdiction will be governed and zoned and provide a framework for local regulation and standards, providing a unique local interpretation of how the land and buildings should be used. Finally, unlike economic development documents-which have been well studied (see Arku, 2014; Cleave, Arku, \& Chatwin, 2017, 2019; Cleave, Vecchio, Spilsbury, \& Arku, 2019; Reese \& Sands, 2007) - that act as broader strategy guides for cities and their development, Official Plans are legally binding documents that local governments must adhere to when (re)developing their city. As a result, these documents represent a rich text to analyze and understand city priorities and strategy in their response to local economic development change.

Content analysis of city documents is a useful approach to understanding the perspective, strategy, tactics, and framing of issues by identifying, isolating, and describing the way that phenomenon, events, organizations, or programs are perceived and codified by local governments (Bowen, 2009; Kay, 2009). An advantage of document analysis is that broad conclusions can be drawn from a number of sources, as long as they are representative of the population being examined (Chatwin, Arku, \& Cleave, 2019; Cleave et al., 2017; Moynihan, 2006) - which is true in this study as all cities in Ontario are examined. To ensure rigour in the analysis and validity of findings, a comprehensive approach was used to catalogue, classify, and analyze the content of the Official Plans. Initially, the complete plans were read independently by the two researchers to "achieve immersion and obtain a sense of the whole" (Hsieh \& Shannon, 2005, p. 1279), and to conceptualize the broad understanding of land-use policy within each municipality. Following this initial read-through, a set of thematic codes was established based on a collection of data using a bank of key words related to the topic. 18 themes were initially found in the first comprehensive read through by the two researchers. Subsequently, these themes were then scrutinized and consolidated (based on repetition and redundancy) to the 10 used in this study (Table 1). The documents were then read a second time to assign content to each relevant theme. Afterwards, occurrences were doc- 
umented using NVivo software to quantify incidences for each thematic code. These themes were then examined to understand the ways cities in Ontario are deal- ing with manufacturing decline and the resulting urban change, which is expanded upon in the results section of this article.

Table 1. Summary of theme consolidation process.

\begin{tabular}{lll}
\hline Original Theme List & Consolidated Theme List & Theme Description \\
\hline Planning for an economic transition & $\begin{array}{l}\text { Acknowledgement of } \\
\text { Industrial Decline and }\end{array}$ & $\begin{array}{l}\text { An overall recognition by the policy document } \\
\text { that economic changes (predominantly }\end{array}$ \\
$\begin{array}{l}\text { Deindustrialization and the increase of } \\
\text { the service economy }\end{array}$ & $\begin{array}{l}\text { Economic Transition } \\
\text { occurring from industrial decline) require }\end{array}$ \\
$\begin{array}{l}\text { Increased incidences of brownfields and } \\
\text { closed factories }\end{array}$ & & $\begin{array}{l}\text { perspective. } \\
\text { pections from a land planning }\end{array}$
\end{tabular}

An employment shift within the urban

area from manufacturing to service

employment

Encouraging specific industrial

employers to move to more appropriate land types

Support the Relocation of Industrial Uses to Targeted Employment Lands

Make employment land available to attract both new and existing industrial employers

Specific policy for a closed down industrial building.

Specific policy for a neighbourhood-wide derelict industrial land issue.

Reuse as a Tool for Affordable Housing

Reduction of urban sprawl by retooling the existing built environment.

Meeting increased density targets by utilizing vacant buildings within the core.

Reducing core vacancies by encouraging alternative economic uses of existing buildings.

Encourage the conversion of buildings to commercial, office, and high density residential within the core areas.

Creation of a Community Improvement Plan for Brownfield

Reuse/Redevelopment

Reuse of Industrial Buildings to Light Industrial Uses

Non-CIP related financial incentives.

Unique Policy that Promotes reuse.

Strong Protection from Building or Site Conversion within Employment Lands
Reuse as a Tool for Revitalization of the Urban

Core

Site Specific Targeting Area for Industrial Reuse of Redevelopment

Reuse as a Tool for Affordable Housing

Reuse as a tool for Intensification

\section{Creation of a Community} Improvement Plan for Brownfield Reuse/Redevelopment

Reuse of Industrial Buildings to Light Industrial Uses

Grants, Subsidies, or Unique Policy that Promotes Industrial Reuse

Strong Protection from Building or Site Conversion within Employment Lands
Policy measures that enable more sensitive lands within an urban core to be freed up for the possibility of adaptive reuse, while existing employers operate in specific employment lands.

Policy which targets specific locations or neighbourhoods where industrial decline has left underutilized land or buildings.

Identifying the possibility for the adaptive reuse of buildings to increase the housing supply.

Policy which identifies adaptive reuse as a tool to meet provincially and local density targets. This coincides with the reduction of peripheral sprawl and utilization of existing infrastructure.

Policy which identifies adaptive reuse as a tool to mitigate the recent trend of core and downtown decline within Canadian urban centres due to the dependency of suburbs and greenfield development.

Using a Provincially legislated sub-policy to offer financial assistance for community improvement.

Encouraging more compatible industry to other land uses.

These included incentives and policy outside the realm of Community Improvement Plans that enable a stronger environment for reuse.

Policy which was protective of any changes to industrial lands and did not support easy land conversion. 
One limitation of the content analysis format was the lack of ability to capture thematic patterns which were only glanced upon or suggested as possible approaches within the policy documents. As such, it was difficult to quantify broad policy themes as they often did not have the specificity and detailed approach that more targeted policies had. This was especially true when attempting this without breaking from the sound methodological approach above. Though a limitation in this study, the researchers intend to investigate more individual city approaches in future research now that the broad provincial overview has been examined within this article.

As previously noted, the third key concern of this study is investigating whether the local economy (through its industrial base) impacts what policies appear in these plans. In short, are the themes that emerged from the content analysis different between cities at different economic stages-particularly related to manufacturing and its decline? To categorize cities, a location quotient (LQ) of the Goods Producing Labour Force of each city was used to compare its concentration within the economic base of cities in Ontario. Employment data was collected from Statistics Canada and comprises of information from the 2016 Census. Goods Producing Industries are defined as the combination of the North American Industry Classification System codes 11 to 33 (Statistics Canada, 2020), which provides a standardized classification cut off for the calculation of LQs. The local sums of these industries were divided by the local labour force, equating to the proportion of the city's labour force that was in the goods producing sector. Each proportion was then divided by the province-wide equivalent. The cities were then divided into four groups (Table 2) based on whether their LQ was 1.25 and above (High Industrial Base), 1.0-1.24 (Moderate Industrial Base), 0.75-0.99 (Moderate Non-Industrial Base), and 0.74 and below (High Non-Industrial Base). This classification is adapted from previous studies (Baer \& Brown, 2006; McLean \& Voytek, 1992) where targeted LQ cut offs of above 1.25 and below 0.75 were considered significant from a policymaker's perspective. Descriptive statistics were used to summarize the themes that emerged in the content analysis, allowing a comparison of the strategies of cities with different compositions in their economic base. This descriptive approach allows for an in-depth analytical examination, complementing and extending the qualitative and policy findings of the content analysis.

\section{Results}

All 51 cities in the Province of Ontario had an Official Plan. Both the mean and median of the plans were nine years old, ranging from 33 years (Brantford) to one (Norfolk County) seen in Table 2. 45 of the plans were written in-house by planners, while the remaining six used private consultants to formulate a plan for council approval. Within the Official Plans, local economic development themes were prevalent across all cities-every Official Plan analyzed contained at least two themes, ranging from two (Prince Edward County) to 10 (Windsor), with an average of 5.85 themes appearing in each document (Table 2). There were ten themes that emerged from the content analysis (Table 3 ). Although wide-ranging in focus, these ten themes do form three larger clusters of development strategy: (1) framing and planning; (2) industry-focused land reuse; and (3) urban-focused land reuse.

\subsection{Framing and Planning Themes}

The framing and planning cluster focuses on broader issues of governance and addressing local economic growth through key themes of 'Acknowledgement of Industrial Decline and Economic Transition,' the 'Creation of a Community Improvement Plan for Brownfield Reuse/Redevelopment,' and 'Grants, Subsidies, or a Unique Policy That Promotes Industrial Reuse.' These represent 'high-level' efforts by the cities to engage with issues of manufacturing decline. Notably, there was a pattern between whether this framing was included in the Official Plan and the city's industrial base (Table 4). The relationship between LQ and the themes contained in the Official Plans were tested for independence, though no significant result was found (using Chi-square). This suggests that there is homogeneity in the approaches cities use to contextualise and form policy. However, this study is in the uncommon position of analysing the entire population, so descriptive statistics will be used to describe the findings of the content analysis and draw conclusions. Cities with a high industrial base $(100 \%)$ acknowledge industrial decline and an economic transition more often than those with a small base (50\%). Similarly, high industrial based cities more frequently include policy measures like enacting Community Improvement Plans (91\%) and unique grants and policies (55\%), which are tangible tools to reuse former industrial lands for more sensitive uses. Inversely, it was the high non-industrial based cities that were more likely to support strong employment land policy (88\%), compared to high industrial based cities (45\%). A potential explanation for this pattern is that many of the cities which make up the high non-industrial based grouping are those surrounding Toronto, whose expansive residential, commercial, and office-built environment, makes industrial lands in high demand.

'Acknowledgement of Industrial Decline and Economic Transition' was the most common theme of the analysis as $81 \%$ of the Official Plans had some reference to economic decline and the need to plan for a transitioning economy. This theme is unique, as it is not a specific policy initiative, but rather a contextual framing of the changes and challenges that cities face. For example, the City of Elliot Lake (2018, p. 23) frames itself as, "a young, progressive community in a state of transition." Expanding on this, the City of Burlington's 
Table 2. City characteristics.

\begin{tabular}{|c|c|c|c|c|c|}
\hline City & Population & $\begin{array}{l}\text { Original Date } \\
\text { of Plan Creation }\end{array}$ & LQ & LQ Category & $\begin{array}{l}\text { \# of Theme } \\
\text { Occurrences }\end{array}$ \\
\hline Barrie & 141,434 & 2010 & 0.95 & Moderate Non-Industrial Base & 5 \\
\hline Belleville & 50,716 & 2002 & 0.87 & Moderate Non-Industrial Base & 6 \\
\hline Brampton & 593,638 & 2006 & 1.01 & Moderate Industrial Base & 4 \\
\hline Brant & 36,707 & 2012 & 1.55 & High Industrial Base & 9 \\
\hline Brantford & 97,496 & 1988 & 1.28 & High Industrial Base & 5 \\
\hline Brockville & 21,346 & 2011 & 0.86 & Moderate Non-Industrial Base & 6 \\
\hline Burlington & 183,314 & 2008 & 0.81 & Moderate Non-Industrial Base & 4 \\
\hline Cambridge & 129,920 & 2018 & 1.41 & High Industrial Base & 8 \\
\hline Clarence-Rockland & 24,512 & 2020 & 0.91 & Moderate Non-Industrial Base & 6 \\
\hline Cornwall & 46,589 & 2018 & 0.84 & Moderate Non-Industrial Base & 7 \\
\hline Dryden & 7,749 & 2011 & 0.94 & Moderate Non-Industrial Base & 3 \\
\hline Elliot Lake & 10,741 & 2018 & 0.88 & Moderate Non-Industrial Base & 5 \\
\hline Greater Sudbury & 161,531 & 2006 & 1.02 & Moderate Industrial Base & 5 \\
\hline Guelph & 131,794 & 1994 & 1.25 & Moderate Industrial Base & 8 \\
\hline Haldimand County & 45,608 & 2006 & 1.57 & High Industrial Base & 6 \\
\hline Hamilton & 536,917 & 2009 & 1.02 & Moderate Industrial Base & 8 \\
\hline Kawartha Lakes & 75,423 & 2006 & 1.24 & Moderate Industrial Base & 4 \\
\hline Kenora & 15,096 & 2015 & 0.87 & Moderate Non-Industrial Base & 6 \\
\hline Kingston & 123,798 & 2010 & 0.50 & High Non-Industrial Base & 4 \\
\hline Kitchener & 233,222 & 2014 & 1.17 & Moderate Industrial Base & 3 \\
\hline London & 383,822 & 2016 & 0.82 & Moderate Non-Industrial Base & 6 \\
\hline Markham & 328,966 & 2014 & 0.68 & High Non-Industrial Base & 2 \\
\hline Mississauga & 721,599 & 2010 & 0.83 & Moderate Non-Industrial Base & 3 \\
\hline Niagara Falls & 88,071 & 1993 & 0.74 & High Non-Industrial Base & 3 \\
\hline Norfolk County & 64,044 & 2019 & 1.65 & High Industrial Base & 8 \\
\hline North Bay & 51,553 & 2012 & 0.67 & High Non-Industrial Base & 6 \\
\hline Orillia & 31,166 & 2010 & 0.81 & Moderate Non-Industrial Base & 7 \\
\hline Oshawa & 159,458 & 2018 & 0.99 & Moderate Non-Industrial Base & 5 \\
\hline Ottawa & 934,243 & 2003 & 0.41 & High Non-Industrial Base & 4 \\
\hline Owen Sound & 21,341 & 2017 & 1.00 & Moderate Industrial Base & 9 \\
\hline Pembroke & 13,882 & 2016 & 0.70 & High Non-Industrial Base & 3 \\
\hline Peterborough & 81,032 & 2017 & 0.73 & High Non-Industrial Base & 8 \\
\hline Pickering & 91,771 & 1997 & 0.80 & Moderate Non-Industrial Base & 4 \\
\hline Port Colborne & 18,306 & 2013 & 1.22 & Moderate Industrial Base & 9 \\
\hline Prince Edward County & 24,735 & 1993 & 1.20 & Moderate Industrial Base & 2 \\
\hline Quinte West & 43,577 & 2011 & 1.07 & Moderate Industrial Base & 7 \\
\hline Sarnia & 71,594 & 2016 & 1.07 & Moderate Industrial Base & 9 \\
\hline Sault Ste. Marie & 73,368 & 2013 & 0.93 & Moderate Non-Industrial Base & 6 \\
\hline St. Catherine's & 133,113 & 2010 & 0.88 & Moderate Non-Industrial Base & 8 \\
\hline St. Thomas & 38,909 & 2018 & 1.25 & High Industrial Base & 6 \\
\hline Stratford & 31,465 & 2017 & 1.39 & High Industrial Base & 8 \\
\hline Temiskaming Shores & 9,920 & 2015 & 1.11 & Moderate Industrial Base & 2 \\
\hline Thorold & 18,801 & 2015 & 0.88 & Moderate Non-Industrial Base & 5 \\
\hline Thunder Bay & 107,909 & 2018 & 0.78 & Moderate Non-Industrial Base & 9 \\
\hline Timmins & 41,788 & 2009 & 1.30 & High Industrial Base & 4 \\
\hline Toronto & $2,731,571$ & 2015 & 0.64 & High Non-Industrial Base & 6 \\
\hline Vaughan & 306,233 & 2017 & 0.97 & Moderate Non-Industrial Base & 5 \\
\hline Waterloo & 104,986 & 2012 & 0.77 & Moderate Non-Industrial Base & 7 \\
\hline Welland & 52,293 & 2010 & 0.94 & Moderate Non-Industrial Base & 8 \\
\hline Windsor & 217,188 & 2013 & 1.25 & High Industrial Base & 10 \\
\hline Woodstock & 40,902 & 1995 & 1.55 & High Industrial Base & 8 \\
\hline AVERAGE & 187,917 & & & & 5.85 \\
\hline
\end{tabular}


Table 3. Theme clusters and characteristics.

\begin{tabular}{ccc}
\hline \# of Occurrences & \\
Theme & in Plans & Characteristics
\end{tabular}

Framing and Planning

Acknowledgment of

Industrial Decline and

Economic Transition

Creation of a Community

Improvement Plan

for Brownfield

Reuse/Redevelopment

Grants, Subsidies, or a

Unique Policy that

Promotes Industrial Reuse

Industry-Focused Land Reuse

Support the Relocation of

Industrial Uses to Targeted

Employment Lands

Site Specific Targeting Area

for Industrial Reuse or

Redevelopment

Reuse of Industrial Buildings

to Light Industrial Uses

Urban-Focused Land Reuse

Reuse as a Tool for

Affordable Housing

Reuse as a Tool for

Intensification

Reuse as a Tool for

Revitalization of the

Urban Core

Strong Protection From

Building or Site Conversion

within Employment Land
18
These themes represent 'high-level' efforts by the cities to engage with issues of manufacturing decline. Ranging from the recognition of economic trends-suggesting a shift from manufacturing to service-based industries, to specific financial measures and unique policies that actively target industrial decline within communities.
This cluster includes specific strategies that the cities use to support, maintain, and locate remaining industry within their jurisdiction to more appropriate lands. These themes shared a commonality of mitigating isolated traditional manufacturing buildings for more appropriate uses to the surrounding community. This included pure relocation efforts to employment lands, or refitting buildings for light, more 'community friendly' industry such as artisanal companies like bakeries, craft breweries and butchers.

This group of themes emphasized ways former industrial lands could be re-deployed to address urban development goals. With both provincially mandated and municipal set urban growth goals, cities are creating policy to meet the common standards of higher density, increased affordable housing, and the revitalization of underutilized lands. Adaptive reuse was suggested by the policy as a tool to meet these goals within communities. Equally important, was policy from some cities that stated the importance of protecting industrial lands from possible redevelopment or conversion.
Official Plan (2018, p. 138) provides greater description of the transition occurring and the challenges it faces: "The manufacturing-based economy has entered a period of transition where issues of globalization, technology changes, including automation and labour force changes, all contribute to a new role in the economy for manufacturing."

Along with the "Creation of a Community Improvement Plan for Brownfield or Industrial Reuse' and 'Grants, Subsidies, or a Unique Policy that Promotes Industrial Reuse' these themes create a framework for policy development. The City of Hamilton (2013, p. 36), for instance, has a measure to incentivize reuse, and policy goal of the city is "to facilitate the intensification and adaptive reuse of such properties...allow reduced parking or other site and amenity requirements." This idea of compromising on certain city requirements was a common theme across the board, though it formulated itself in different ways. Norfolk County (2019, p. 240) used a bonusing approach indicating that "brownfield sites may be developed at densities higher than 75 units per hectare, without amendment to this Plan, but should be of a scale and massing that is generally consistent with the Residential, Medium Density designations." Similarly, the City of Belleville (2002, p. 52) entices reuse with a circumvention of lengthy and costly Official Plan amendments:

Where re-use of any land designated Industrial land use on the land use schedules for a purpose other than industrial is proposed and the alternative use is in keeping with the main objective for the Bayshore planning area, such reuse may be permitted without amendment to this Plan. 
Table 4. Thematic descriptions by economic base.

\begin{tabular}{|c|c|c|c|c|}
\hline & $\begin{array}{c}\text { High } \\
\text { Industrial Base } \\
(n=11)\end{array}$ & $\begin{array}{l}\text { Moderate } \\
\text { Industrial Base } \\
\quad(n=11)\end{array}$ & $\begin{array}{c}\text { Moderate } \\
\text { Non-Industrial Base } \\
(\mathrm{n}=21)\end{array}$ & $\begin{array}{c}\text { High } \\
\text { Non-Industrial Base } \\
(\mathrm{n}=8)\end{array}$ \\
\hline $\begin{array}{l}\text { Acknowledgement of Industrial Decline } \\
\text { and Economic Transition }\end{array}$ & $\begin{array}{c}11 \\
(100 \%)\end{array}$ & $\begin{array}{c}10 \\
(91 \%)\end{array}$ & $\begin{array}{c}16 \\
(76 \%)\end{array}$ & $\begin{array}{c}4 \\
(50 \%)\end{array}$ \\
\hline $\begin{array}{l}\text { Creation of a Community Improvement } \\
\text { Plan for Brownfield Reuse/Redevelopment }\end{array}$ & $\begin{array}{c}10 \\
(91 \%)\end{array}$ & $\begin{array}{c}7 \\
(58 \%)\end{array}$ & $\begin{array}{c}17 \\
(81 \%)\end{array}$ & $\begin{array}{c}5 \\
(63 \%)\end{array}$ \\
\hline $\begin{array}{l}\text { Grants, Subsidies, or a Unique Policy that } \\
\text { Promotes Industrial Reuse }\end{array}$ & $\begin{array}{c}6 \\
(55 \%)\end{array}$ & $\begin{array}{c}4 \\
(36 \%)\end{array}$ & $\begin{array}{c}7 \\
(33 \%)\end{array}$ & $\begin{array}{c}1 \\
(13 \%)\end{array}$ \\
\hline $\begin{array}{l}\text { Support the Relocation of Industrial Uses } \\
\text { to Targeted Employment Lands }\end{array}$ & $\begin{array}{c}8 \\
(73 \%)\end{array}$ & $\begin{array}{c}6 \\
(55 \%)\end{array}$ & $\begin{array}{c}8 \\
(38 \%)\end{array}$ & $\begin{array}{c}3 \\
(38 \%)\end{array}$ \\
\hline $\begin{array}{l}\text { Site Specific Targeting Area for Industrial } \\
\text { Reuse or Redevelopment }\end{array}$ & $\begin{array}{c}10 \\
(91 \%)\end{array}$ & $\begin{array}{c}8 \\
(73 \%)\end{array}$ & $\begin{array}{c}16 \\
(76 \%)\end{array}$ & $\begin{array}{c}6 \\
(75 \%)\end{array}$ \\
\hline $\begin{array}{l}\text { Reuse of Industrial Buildings to Light } \\
\text { Industrial Uses }\end{array}$ & $\begin{array}{c}7 \\
(64 \%)\end{array}$ & $\begin{array}{c}5 \\
(45 \%)\end{array}$ & $\begin{array}{c}4 \\
(19 \%)\end{array}$ & $\begin{array}{c}0 \\
(0 \%)\end{array}$ \\
\hline Reuse as a Tool for Affordable Housing & $\begin{array}{c}3 \\
(27 \%)\end{array}$ & $\begin{array}{c}1 \\
(9 \%)\end{array}$ & $\begin{array}{c}6 \\
(29 \%)\end{array}$ & $\begin{array}{c}4 \\
(50 \%)\end{array}$ \\
\hline Reuse as a Tool for Intensification & $\begin{array}{c}10 \\
(91 \%)\end{array}$ & $\begin{array}{c}8 \\
(73 \%)\end{array}$ & $\begin{array}{c}18 \\
(86 \%)\end{array}$ & $\begin{array}{c}4 \\
(50 \%)\end{array}$ \\
\hline $\begin{array}{l}\text { Reuse as a Tool for Revitalization of } \\
\text { the Urban Core }\end{array}$ & $\begin{array}{c}10 \\
(91 \%)\end{array}$ & $\begin{array}{c}7 \\
(64 \%)\end{array}$ & $\begin{array}{c}13 \\
(62 \%)\end{array}$ & $\begin{array}{c}2 \\
(25 \%)\end{array}$ \\
\hline $\begin{array}{l}\text { Strong Protection from Building or Site } \\
\text { Conversion within Employment Land }\end{array}$ & $\begin{array}{c}5 \\
(45 \%)\end{array}$ & $\begin{array}{c}6 \\
(55 \%)\end{array}$ & $\begin{array}{c}16 \\
(76 \%)\end{array}$ & $\begin{array}{c}7 \\
(88 \%)\end{array}$ \\
\hline Average & $\begin{array}{c}8 \\
(73 \%)\end{array}$ & $\begin{array}{c}6 \\
(56 \%)\end{array}$ & $\begin{array}{c}6 \\
(29 \%)\end{array}$ & $\begin{array}{c}5 \\
\text { (63\%) }\end{array}$ \\
\hline
\end{tabular}

Similarly, the creation of Community Improvement Plans was by far the most common tool for promoting adaptive reuse and the related brownfield redevelopment. $75 \%$ of cities either had one in place or would consider the implementation of one. Made available by the province in the Planning Act of 1990 (Government of Ontario, 1990), Community Improvement Plans are plans that focus on the maintenance or rehabilitation of targeted areas, in which municipalities can make grants, loans, or tax programs to help pay for certain costs. These grant and loan programs are available for the city to setup in an attempt to promote reuse and brownfield redevelopment and is one of the few provincially mandated tools to address these issues.

\subsection{Industry-Focused Policies}

The industry-focused land reuse of grouping of themes focused on specific strategies that the cities used to support, maintain, and locate remaining industry within their jurisdiction. This includes 'Support the Relocation of Industrial Uses to Targeted Employment Lands, Site Specific Targeting Area for Industrial Reuse of Redevelopment,' and 'Reuse of Industrial Buildings to
Light Industrial Uses.' Cities on a whole, targeted specific sites within their plans for redevelopment or reuse of industrial lands and buildings, this does not appear to change when accounting for industrial base composition (Table 4). This, however, is contrasted with policies that supported the relocation of existing industry to employment lands. For these policy tools, the high (73\%) and moderate industrial based cities (55\%) were more likely to include this tool in their policy than cities with lower concentrations of industry (38\%). This result is not surprising, as one would assume that cities which are dependent on industry would likely have more focused industrial lands on which to move existing businesses. Finally, cities with a high industrial base (64\%) and moderate base $(45 \%)$ indicated in their policy the idea of transitioning traditional industrial buildings into more community sensible light-industry uses. When comparing this to moderately non-industrial bases (19\%) and high nonindustrial bases $(0 \%)$, it is clear that cities with larger industrial compositions are actively targeting the transition away from traditional manufacturing, at least in the urban context.

Nearly half of the cities in Ontario indicated that they support the relocation of incompatible industrial 
uses outside of planned employment lands. This often situated itself as pockets of existing industrial uses within predominately residential or commercial areas that were incompatible with the growing use around them. Predictably, these sites serve as prime examples of potential adaptive reuse projects. For example, from London:

Remnant industrial parcels may exist within residential neighbourhoods, in locations where they are no longer compatible with surrounding land uses. On such parcels we will support the relocation of any remaining industrial land uses and the repurposing of these parcels for land uses that are compatible with the neighbourhood context. (City of London, 2016, p. 293)

The targeting of specific sites or areas of cities was widespread amongst the plans (79\% of documents; second most common theme). Cities ranged in specificity from large areas like waterfront areas historically used for industrial purposes (a common theme in several lake bound cities) to more specific identification of individual closed plants. Port Colborne, who cites a goal of converting 150 acres of former industrial to tourism or recreational uses, notes: "The City has been actively involved in assessing and addressing underutilized lands throughout the community. [Specifically] through innovative approaches to brownfield and waterfront development" (City of Port Colborne, 2013, p. 26).

Haldimand County (2006, p. 191) further illustrates more specific targeting:

The potential redevelopment and/or reuse of the former Smucker's plant should have consideration for the comprehensive redevelopment and/or reuse of the property to ensure compatibility with the character of the surrounding area through appropriate street and block patterns, and land use and built form transitions with the residential neighbourhood cluster to the east (Brant Street and Brace Street) and adjacent employment area.

\subsection{Urban Land-Use Policies}

The urban-focused land reuse cluster of themes emphasized ways former industrial lands could be re-deployed to address urban development goals. This grouping of themes included policies on 'Reuse as a Tool for Affordable Housing Reuse, as a Tool for Intensification, as a Tool for Revitalization of the Urban Core,' and 'Strong Protection from Building or Site Conversion within Employment Lands.'

Further, issues surrounding employment lands were often mentioned in the Official Plans. These areas were typically set aside for industrial uses, often near major transportation hubs such as highways, airports, and harbours, and the places that cities were trying to relocate isolated industries to. The stronger the protection of these lands through policy prohibiting conversion to nonemployment uses, and major bylaw amendments and studies that are needed if someone tries, the more unlikely reuse in these areas will occur. Some cities, however, were more open to conversion of these lands and indicated that reuse in these areas could still be beneficial. The City of Vaughan's (2017, p. 302) plan, for example, is "supporting the reuse and/or repurposing of older industrial buildings and/or Employment Areas for cleaner and more affordable employment uses." Other cities like Brampton (2006, p. 74) were much more protective of their lands, noting: "Conversion of industrial or employment land will not be permitted unless it is assessed as part of a comprehensive review in accordance with the Provincial Policy Statement." Congruently, it was cities with a high non-industrial base (88\%) and moderate non-industrial base (76\%) that included strong employment land protection measures in their policy. When comparing this to moderate industrial based cities (55\%) and high industrial based cities (45\%) it is clear that cities which cannot provide vast swaths of land (especially those situated in urban dense regions like the Greater Toronto Area) are much more protective of their existing stock.

The City of Belleville (2002, p. 65), for example, discussed its West Village area as a target for intensification through reuse:

The West Village neighbourhood is on the west side of the Moira River north of Bridge Street with older industrial and warehousing uses. Some of the intensification opportunities are: Conversion of the historic industrial buildings that back onto the River into loft condominium apartments or live/work spaces; Wherever possible, turning new infill development to face the river and add decking or terraces; Reclaiming or preserving public access to the River; and maintain and upgrade the street housing along Coleman Street.

In addition, nearly two-thirds of cities identified 'Reuse as a Tool for Revitalization of the Downtown Core.' The City of Peterborough (2017, p. 234) discussed core revitalization through reuse:

The Industrial Conversion Area is situated in the southwest portion of the Central Area and recognizes a node of old, predominately single-storey industrial buildings. The focus of the Industrial Conversion Area is to provide policy flexibility allowing industrial buildings and sites to be utilized for a wide variety of alternative uses including retail commercial uses, office and studio uses, institutional and recreational uses, service commercial and service industrial activities.

Finally, it was cities which had a high non-industrial base (50\%) that proposed 'Reuse as a tool for Affordable Housing' compared to the next three industry-based 
groups ( $29 \%, 9 \%$, and $27 \%$ respectively). When considering that cities in the high-non industrial base also include some of the Province's most expensive cities to live (Toronto, Ottawa, and Markham), it is not unexpected to see them actively addressing affordable housing issues with reuse.

\section{Discussion and Conclusion}

This research considers the implications of manufacturing decline and economic change on land planning policy-specifically focusing on how former industrial lands are being, or planned to be, used. Several findings provide distinct conclusions of how cities in Ontario are planning for this change. Firstly, it was evident from the collection of documents the wide range of composition of planning and policy. On the whole, Ontario cities do acknowledge that the economy is in transition, resulting in an influx of underutilized industrial lands. This replicates findings in Cleave, Vecchio, et al. (2019), who found that manufacturing decline was an established theme within a city's economic development plan. Although, the goal of an Official Plan is not necessarily to account for economic development policy, it is notable that there is congruence with land-use policy. It was clear cities with higher industrial composition (Tables 2 and 4) generally employed the policies and themes identified here at higher rates than those with smaller industrial bases. This suggests that cities that still have some remaining industry are both more acutely aware of the potential for losing it and are being pre-emptive in ensuring there are plans to efficiently and effective use this land to stabilize and support urban and economic development. What is interesting about this finding is that existing literature typically asserts that smaller cities are disproportionately affected by economic and industrial decline (Siegel \& Waxman, 2001). This has seemingly set the stage for adaptive reuse to be implemented as a tool to assist in both the transition of the local economy and the reflection of the economy in the built environment.

Within the plans, it was clear that cities preferred a site-specific targeted approach, rather than a broader city-wide initiative. Though city-wide approaches such as a Community Improvement Plan for the city's whole stock of brownfield sites were suggested, the most common approach was targeting specifically in-need areas. What was interesting was that cities with higher industrial bases were more aggressively targeting specific areas, and more precisely, specific sites. The Smucker's plant in Haldimand County was already mentioned, but this was joined with the Bata Shoe Factory in Quinte West, Abitbi Mill in Kenora, Woolen Mill in Kingston, and the Waterford Mill in Norfolk County.

\subsection{Adaptive Reuse: A Unique Policy Tool}

One of the more evident discoveries was the lack of congruence when it came to policy promoting reuse. This was surprising given findings of past studies on economic development policy in the province (e.g., Cleave, Vecchio, et al., 2019). Indeed, previous studies find that cities approached policy in a homogenous, frankly cookie cutter fashion. Reuse policy seems to be a much more localized driven approach, where outside of Community Improvement Plans cities are left to their own creativity and determination to see these sites reused or redeveloped. It is worth noting that during the data collection phase, it was clear that the majority of Official Plans have been created in-house by the municipality itself, not with the use of consultants. Only 6/51 cities used consultants to create their official plans: Brockville, Clarence Rockland, Elliot Lake, Kenora, Prince Edward County, and Timiskaming Shores. It should be noted however that all six of these cities are under 25,000 people (Table 2), which suggests that some smaller cities do not have the in-house facilities to undertake a labour extensive task like formulating an official plan for provincial approval. On an interesting side note-this differs from the approach used by economic development plans, where a small number of prominent consultant firms provide the majority of policy for the province (Cleave, Vecchio, et al., 2019). This suggests there may be a relationship between in-house policy creation and the production of unique strategies to combat industrial decline with adaptive reuse, though further investigation into this phenomenon is necessary.

Emerging from the documents is an indicator of unique planning and land-use approaches for industrial lands in specific historical contexts. For example, the City of Brampton (2006, p. 17) directly addressed this in its plan, stating: "Large-scale industrial development started in Brampton only 40 years ago, but today this sector represents the major employer for Brampton residents. Office and service facilities have followed manufacturing but at a slower pace."

However, Brampton is unique for its short manufacturing history. Adaptive reuse is likely less prevalent in those cities where their industrial building stock is newer and planned in a more sensible fashion. Now that the broad policy themes of the province have been investigated, incorporating a metric to measure historic industrial composition would be an interesting next step to this study.

Notably were the narratives in many water-bound cities, which focused on revitalizing the waterfronts. This makes sense as waterfronts are traditionally important industrial lands used in importing and exporting resources. As the economy has transitioned away from the goods producing sector, there seems to be widespread demand to reclaim the waterfont for more community usable spaces. What once stood as the anchor for industry in Ontario, has now become the hottest area for adaptive reuse, often preserving the industrial architecture for a uniquely reclaimed atmosphere. The City of Owen Sound (2017, p. 124) articulates this within their plan as: "Commercial uses are slowly replacing the industrial uses 
historically located along the eastern harbour. Potential for new development areas exists in the underutilized harbour areas."

The reclamation of waterfronts and the reuse of industrial buildings in these areas best describes the ability of reuse for communities to preserve their industrial past, offer a unique space for living and recreation, and meet the common goals in official plans of environmental remediation and reconnection to the cities natural resources. Reuse has the unique opportunity to both preserve the industrial spirit of these once bustling areas, while also allowing for a transition to the new economy.

A potential limitation of planning policy-specifically relevant to targeted planning and development effortsis that policy in of itself is not a direct indication of actual practice (see Bobrow, Eulau, Landau, Jones, \& Axelrod, 1977). This presents itself when considering the result of Community Improvement Plans being seemingly 'thrown in' by many cities to address reuse. Brownfield Community Improvement Plans read as buzzwords in many plans who showed no further attempts to actually implement one. Obviously, Official Plans serve as the broad stepping stone for other municipal policy, but there is no apparent reason why some cities went into specific detail on the implementation of their Community Improvement Plans while others mostly copied word for word the language in the Planning Act (Government of Ontario, 1990) putting forward that the cities had the opportunity to use Community Improvement Plans as a planning tool.

In a similar vein, intensification was one of the most common concepts in the documents as references to reuse as a tool to intensify a city's building stock was seen in all but 11 plans. Rather aggressive targets set out by the province, have seemed to cause many cities to enter into a frenzy with addressing their own intensification goals. As Peterborough (2017, p. 27) said in their plan: "The City will strive to ensure that at least $10 \%$ of new residential units resulting from new residential development and residential intensification through conversion of non-residential structures, infill and redevelopment, to be affordable housing."

The language itself is a common theme in almost every planning policy: 'Strive to ensure' indicates a rather soft target and was replicated repeatedly when discussing reuse policy.

An interesting aspect of the data presented itself in a temporal fashion, where cities in Ontario have been updating older outdated plans within the last decade. With a median age of nine years and the aforementioned literature discussing the growing number of plant closures since the early 2000s, it is understandable that addressing vacant industrial lands is ever-more pressing for municipal planning offices. Only six plans that remain in the catalogue of Ontario cities were originally drafted before the year 2000 (Table 2). Again, it is important to keep in mind that Official Plans undergo regular revisions and reviews, but what is clear is that as new plans con- tinue to be drafted, industrial decline will be more evident to those writing the policy. Indeed, based on additional research by the authors, new plans in Ontario are largely cyclical in their formation due to the Planning Act (Government of Ontario, 1990) stipulation of continuous updates to the plan. Most cities drafted new plans every 20-35 years, and from the data in Table 2, it is clear that most cities have or are entering a new 'generation' of official plans in the last 10 years. These plans have and will be constructed in an era where the decline of manufacturing is well documented and the principles of policies such as the Growth Act (2005; Government of Ontario, 2005) will be well entrenched in municipal planning policy. Further research into the historic timeline of official plans in Ontario and their context of manufacturing decline between plans of different ages is the next logical step in investigating whether planning policy addressing deindustrialization is path dependent.

Ontario cities have clearly identified that industrial decline requires direct policy in the remediation of plant closure and underutilized industrial lands. Reuse serves as a common theme throughout Official Plans as a tool to address some of the most pressing issues de jour for municipalities. Cities have proposed that affordable housing, intensification, revitalization in the urban core, and creating spaces for creative and vibrant industries can be addressed by the promotion of reuse in the community. For those with strong industrial history, the applicability of reuse allows for communities to preserve their industrial heritage, while at the same time shift uses to the new economy, one where waterfront breweries, reclaimed industrial office space, and manufacturing themed loft apartments have become all the rage. If cities can develop unique policy to their specific local situation, which promotes reuse in their communities, they will be able to harness the positive benefits of this tool.

\section{Acknowledgments}

The authors wish to thank the Social Sciences and Humanities Research Council of Canada (SSHRC), which provided financial support for this project through its Insight Grants. The authors also extend special thanks to the anonymous reviewers for their extremely helpful comments.

\section{Conflict of Interests}

The authors declare no conflict of interests.

\section{References}

Arku, G. (2014). Competition and cooperation in economic development: Examining the perceptions of practitioners in Ontario, Canada. Journal of Urban Affairs, 36(1), 99-118.

Baer, C., \& Brown, T. (2006). Location quotients: A tool for comparing regional industry compositions. Incon- 
text Indiana. Retrieved from http://www.incontext. indiana.edu/2006/march/1.asp

Blair, J. P., \& Premus, R. (1987). Major factors in industrial location: A review. Economic Development Quarterly, 1, 72-85.

Bobrow, D., Eulau, H., Landau, M., Jones, C., \& Axelrod, R. (1977). The place of policy analysis in political science: Five perspectives. American Journal of Political Science, 21(2), 415-433.

Bourne, L., Britton, J. N. H. N., \& Leslie, D. (2011). The greater Toronto region: The challenges of economic restructuring, social diversity and globalization. In L. S. Bourne, T. Hutton, R. G. Shearmur, \& J. Simmons (Eds.), Canadian urban regions: Trajectories of growth and change (pp. 236-268). Oxford: Oxford University Press.

Bowen, G. (2009). Document analysis as a qualitative research method. Qualitative Research Journal, 9(2), 27-40.

Bradford, N. (2010). Economic ideas and development strategy: The case of London, Ontario. Canadian Journal of Urban Research, 19(1), 1-22.

Bunting, T., \& Filion, P. (2006). Canadian cities in transition: Local through global perspectives (3rd ed.). Don Mills, ON: Oxford University Press.

Chatwin, M., Arku, G., \& Cleave, E. (2019). Defining subnational open government: Does local context influence policy and practice? Policy Sciences. https://doi. org/10.1007/s11077-018-09347-7

City of Belleville. (2002). City of Belleville official plan. Belleville: City of Belleville.

City of Brampton. (2006). Our Brampton, our future. Brampton: City of Brampton.

City of Burlington. (2018). Burlington official plan. Burlington: City of Burlington.

City of Elliot Lake. (2018). Official plan for the City of Elliot Lake. Elliot Lake: City of Elliot Lake.

City of Hamilton. (2013). City of Hamilton official plan. Hamilton: City of Hamilton.

City of London. (2016). The London plan. London: City of London.

City of Owen Sound. (2017). The City of Owen Sound official plan. Owen Sound: City of Owen Sound.

City of Peterborough. (2017). The official plan of the City of Peterborough. Peterborough: City of Peterborough.

City of Port Colborne. (2013). City of Colborne official plan. Port Colborne: City of Port Colborne.

City of Vaughan. (2017). City of Vaughan official plan. Vaughan: City of Vaughan.

Cleave, E., Arku, G., \& Chatwin, M. (2017). Cities' economic development efforts in a changing global economy: Content analysis of economic development plans in Ontario, Canada. Area, 49(3), 359-368.

Cleave, E., Arku, G., \& Chatwin, M. (2019). One step forward, two steps back? Examining the influence of consultants on city economic development policy. Canadian Journal of Public Administration, 62(1), 96-121.
Cleave, E., Vecchio, M., Spilsbury, D., \& Arku, G. (2019). Manufacturing change and policy response in the contemporary economic landscape: How cities in Ontario, Canada, understand and plan for manufacturing. Regional Studies, Regional Science, 6(1), 469-495.

Collaton, E., \& Bartsch, C. (1996). Industrial site reuse and urban redevelopment: An overview. Cityscape, 2(3), 17-61.

de Sousa, C. (2017). Trying to smart-in-up and cleanup our act by linking regional growth planning, brownfields remediation, and urban infill in southern Ontario cities. Urban Planning, 2(3), 5-17.

Eidelman, G. (2010). Managing urban sprawl in Ontario: Good policy or good politics? Politics and Policy, 38(6), 1211-1236.

Government of Ontario. (1990a). Planning act (RSO 1990, c. P.13). Toronto: Government of Ontario.

Government of Ontario. (1990b). Ontario heritage act (RSO 1990, c. O. 18). Toronto: Government of Ontario.

Government of Ontario. (2001). Municipal act (S.O. 2001, c. 25). Toronto: Government of Ontario.

Government of Ontario. (2005). Places to grow act (S.O. 2005, c. 13). Toronto: Government of Ontario.

Haldimand County. (2006). The Haldimand County official plan. Haldimand County: Haldimand County.

Hayek, M., Arku, G., \& Gilliland, J. (2010). Assessing London, Ontario's brownfield redevelopment effort to promote urban intensification. Local Environment, 15(4), 389-402.

Hayek, M., Novak, M., Arku, G., \& Gilliland, J. (2010). Mapping industrial legacies: Building a comprehensive Brownfield database in geographic information systems. Planning Practice \& Research, 25(4), 461-475.

Hobor, G. (2013). Surviving the era of deindustrialization: The new economic geography of the urban rust belt. Journal of Urban Affairs, 35(4), 417-434.

Hsieh, H., \& Shannon, S. (2005). Three approaches to qualitative content analysis. Qualitative Health $\mathrm{Re}$ search, 15, 1277-1288.

Kay, A. (2009). Understanding policy change as a hermeneutic problem. Journal of Comparative Policy Analysis: Research and Practice, 11(1), 47-63.

Leffers, D. (2018). Real estate developers' influence of land use legislation in the Toronto region: An institutionalist investigation of developers, land conflict and property law. Urban Studies, 55(14), 3059-3075.

Martin, R., \& Sunley, P. (2006). Path dependence and regional economic evolution. Journal of Economic Geography, 6(4), 395-437. https://doi.org/10.1093/ jeg/lbl012

McLean, M. L., \& Voytek, K. P. (1992). Understanding your economy: Using analysis to guide local strategic planning (2nd ed.). Chicago, IL: Planners Press.

Ministry of Municipal Affairs and Housing. (2005). Provincial policy statement 2005. Toronto: Ministry of Municipal Affairs and Housing. 
Ministry of Municipal Affairs and Housing. (2010). Citizen's guide to official plans. Toronto: Ministry of Municipal Affairs and Housing.

Ministry of Municipal Affairs and Housing. (2014). Provincial policy statement 2014. Toronto: Ministry of Municipal Affairs and Housing.

Moynihan, D. (2006). Managing for results in state government: Evaluating a decade of reform. Public Administration Review, 66(1), 77-89. https://doi.org/ 10.1111/j.1540-6210.2006.00557.x

Norfolk County. (2019). Norfolk County official plan. Norfolk County: Norfolk County.

Reese, L. A., \& Sands, G. (2007). Making the least of our differences? Trends in local economic development in Ontario and Michigan, 1990-2005. Canadian Public Administration, 50(1), 79-99.

Sands, G. (2010). Prosperity and the new economy in Canada's major city regions. GeoJournal, 75(6),
539-552.

Shipley, R., Utz, S., \& Parsons, M. (2006). Does adaptive reuse pay? A study of the business of building renovation in Ontario, Canada. International Journal of Heritage Studies, 12(6), 505-520.

Siegel, B., \& Waxman, A. (2001). Third-tier cities: Adjusting to the new economy. Reviews of Economic Development Literature and Practice, 6, 1-38.

Statistics Canada. (2020). 2016 census: Employment by industry, census metropolitan areas. Ontario: Statistics Canada.

Ward, S. V. (1998). Selling places: The marketing and promotion of towns and cities 1850-2000. London: E \& FN Spon.

Wilson, C. A. (2010). Adaptive reuse of industrial buildings in Toronto, Ontario evaluating criteria for determining building selection (Unpublished Master's dissertation). Queen's University, Kingston, Canada.

\section{About the Authors}

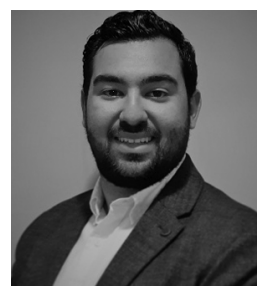

Marcello Vecchio is a Graduate Student at Western University in London, Ontario. His research involves industrial decline in Ontario and the adaptive reuse of former industrial buildings in urban areas. Along with his colleagues at Western, he also researches broader economic development phenomena and how cities are responding to a changing economy. Apart from academia, he also has experience in both urban planning and development finance.

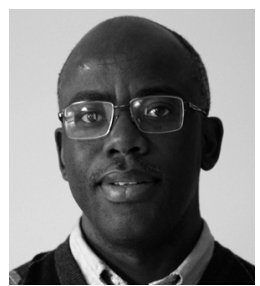

Godwin Arku is an Associate Professor in Geography at Western University in London, Ontario. His research spans 'urban' and 'economic' sub-divisions of human geography, especially as they relate to the transformation of urban systems in a changing global environment. He is the Principal Investigator of PCLIP (Plan Closures: Local Impact and Policy) and has extensive experience with combining qualitative and quantitative research methods on issues related to economic development policy and practices, manufacturing, and urban geography. 